\title{
Measuring the Effect of Massage Therapy on Anxiety of Heart Failure Patients
}

\author{
Somayeh Ramezanli ${ }^{1}$, Marzieh Kargar Jahromi ${ }^{1}$, \\ Maliheh Talebizadeh $^{1}$ and Farzad Poorgholami ${ }^{2 *}$
}

\author{
${ }^{1}$ Nursing Department, Jahrom University of Medical Sciences, Jahrom , Iran. \\ ${ }^{2}$ Research Center for Social Determinants of Health, \\ Jahrom University of Medical Sciences, Jahrom , Iran.
}

http://dx.doi.org/10.13005/bbra/2051

(Received: 01 February 2016; accepted: 12 March 2016)

\begin{abstract}
Congestive Heart failure (CHF) is one of the most common chronic diseases. The objective of this study was to assess whether back massage could release anxiety in patients with CHF. The study used a quasi-experimental design with one group pretest and posttest. Fifty participants were recruited in study. The modified State Anxiety Inventory was used in this study. The baseline overall mean score of anxiety was 43.52 (10.32) in the intervention group and was decreased to $33.22(5.19)$ three days after massage therapy $(p=0.01)$. The conclusion that back massage can be more helpful to male patients than female patients. This study was conducted without a control group.
\end{abstract}

Keyword: Back Massage, Patients, Anxiety, Heart Failure.

Congestive Heart failure (CHF) is one of the most common chronic diseases and major causes of mortality in the world with high hospital admissions (Abu Ruz, Lennie, \& Moser, 2011). Negative emotions (i.e., anxiety and depression) appear to be more common in patients with CHF than in healthy individuals (Chen, Clark, Tai, \& Lin, 2010. Moser \& Worster, 2000).

Different methods have been applied to reduce anxiety and its consequences. Therapeutic touch and massage are of the oldest anxiolytic methods (Sherman et al, 2005).

Massage therapy (MT) is a technique that promotes the manual mobilization of several structures from both muscle and subcutaneous tissue, by applying mechanical force to tissues. This mobilization improves lymph movement and venous return; reduces swelling; and mobilizes muscle fibers, tendons and skin. Thus, MT may

\footnotetext{
* To whom all correspondence should be addressed. Tel.: 98-71-5434-1501;

E-mail:FarzadPoorgholami1393@gmail.com
}

be used to promote muscle relaxation and to reduce pain, stress and anxiety (Anderson \& Cutshall, 2007).

Although there have been more studies assessing the impacts of massage on the treatment of medical conditions, there has been no research done to assess whether massage therapy reduces anxiety in patients with CHF.

\section{MATERIALANDMETHODS}

\section{The study design}

A quasi-experimental study was conducted with the permission of Jahrom University of Medical Sciences. The study was done in two coronary care unit (CCU) wards of Jahrom University of medical science, Iran. The 50 participants invited to the study after daily reviewing of the patients' files of CCU wards and consulting with their physicians.

\section{Sample Size}

On the basis of the previous research the estimated number of samples for study was 
estimated to be 45 patients $( \pm=0.05,1-2=0.80,1 / 41$ $1 / 42=4.84$ ). However 50 patients were selected to compensate the possible attrition.

\section{Inclusion criteria}

The criteria for inclusion: The participants were diagnosed with NYHA Class I-IV heart failure by a cardiac specialist, being literate, being conscious, and a length of stay more than 3 days, and willing to participate in the study.

\section{Exclusion criteria}

The participants excluded from study if they have some confounders, such as a thrombosis greater than $1 \mathrm{~cm}$ by the Doppler echography, backpressure ulcers, acute pulmonary edema, respiratory failure, or cardiac tamponed, a cardiac arrest in the past 72 hours, severe dyspnea, a cardiac pacemaker, a pulse rate less than $60 / \mathrm{min}$, a dialysis fistula and a history of bone fracture in the past 2 months and a history of receiving massage therapy were excluded.

\section{Procedure}

The patients participated in this study within 24 hours after admission to the coronary care unit.

The massages therapy was started 3 days after admission in hospital in order not to disturb their medical regimen plan.

Protocols for this procedure varied in previous studies (Richards, 2010). The intensity and time of massage therapy ranged from one session of 3-45 minutes to 15 sessions over 4 weeks (Jane, Wilkie, \& Gallucci, 2008). In this article the time of massage therapy in considered for 10 minutes. Back massage was lasted 10 minutes each day for 3 days consecutively. Back massage intervention included pressing and stroking (effleurage), kneading (petrissage), rubbing with short strokes, tapping (percussion), and rubbing with long strokes (friction).

Back massage was done one hour before a meal or two hours after a meal. Before the massage, each participant was asked to sit up and position himself/herself on a bedside table with a pillow to cushion.

Massage is an intervention that can be implemented in practice, whether by health professionals or parents, but specific guidelines are necessary for its implementation, including the rhythm, pressure, direction, duration, and frequency. All massage treatments will be performed by licensed massage therapists who have at least 5 years' experience.

\section{Instrument}

Mahram in 1994 has translated the SAI in Farsi. He has got reliability of 0.94 by Cronbach's Alpha. For validity of the test the comparison of mean of anxiety of the standard community in all age ranges in two levels of $5 \%$ and $1 \%$ have been achieved. The Farsi inventory has been repeatedly used and evaluated among various groups and its validity and reliability have been measured (Dehghan-nayeri \& Adib-Hajbaghery, 2011. Mahram, 1994).

The modified SAI was used to measure anxiety. The patients described perceptions from back massage as follows: "relaxed," "comfortable," "glad,” " "joyful,” "at ease," after the back massage.

The modified SAI used a 4-point Likert scale. The maximum score was 80 points, and the minimum 20; the higher the score, the higher the anxiety.

\section{Data analysis}

The effect of Back massage on anxiety level was assessed with the paired t-test and repeated-measures analysis of variance.

\section{Ethical considerations}

This study was approved by the Research Council and the Research Ethics Committee of Jahrom University of Medical Sciences. The researchers also obtained permission from the hospital authorities. All of the subjects informed about being free to participate in the research, nondisclosure of personal information and were offered the written informed consent form to be signed before entering the study. The researchers were mindful of the need to pay close attention to ethical considerations and to the welfare of research participants.

\section{RESULT}

The participants consisted of 50 individuals. The proportion of male and female participants was 41.35. The mean age of the total cases was 69.13 ( $\mathrm{SD}=11.82$ ) years. Totally, $89.16 \%$ of the patients were married, $68.33 \%$ were employed and the others were retired or unemployed. The education of most of patients (58.33\%) was at the level of primary school and the rest was at the level of secondary school or higher education. 
None of the patients had a history of massage therapy. With regard to the particular features of their conditions, the largest group (45.72) had been diagnosed with CHF less than 6 months earlier; most participants (70.31\%) were NYHA class III

Table 1. Demographic Data of Research Participants

\begin{tabular}{lc}
\hline Characteristic & Value \\
\hline Mean age (years) & 69.13 (SD=11.82) \\
Sex [\% (women/men)] & $41 / 35$ \\
Level of education & 58.33 \\
Elementary & 41.67 \\
Secondary or higher & \\
Marital status & 89.16 \\
Married & 10.84 \\
Single or widowed & \\
Employment & 68.33 \\
Employed & 31.67 \\
Retired or Unemployed & \\
CHF* Diagnose & 45.72 \\
less than 6 months & 54.28 \\
6 months or more & \\
CHF classe & 6.33 \\
I & 23.36 \\
I I & 70.31 \\
I I I & \\
\hline
\end{tabular}

* Congestive Heart failure (marked limitation of physical activity, only comfortable at rest).(Table 1).

As shown in Table 2, after back massage, participants had significantly reduced anxiety $(\mathrm{p}<$ 0.01) compared to pre massage. (Table 3

\section{DISCUSSION}

In the current study, after massage therapy the male participants showed a significantly greater reduction in anxiety than the female participants.

Females reported significantly higher levels of test anxiety than males. This is consistent with the previous researches on gender effects on test anxiety (Lashkaripour,2006. Mousavi, Haghshenas, \& Alishahi, 2008).

Moser et al. reported that patients' anxiety levels were correlated with their gender, age, and educational level (Moser, Dracup, \& Evangelista, 2010).

Massage seems to relax the muscles (Buttagat, Eungpinichpong, Chatchawan, \& Kharmwan, 2011) and decreases norepinephrine (Braun \& Simonson, 2014) that consequently will result in reduced anxiety. Our results showed that massage therapy reduces anxiety in patients admitted to CCU. In a previous study it has reported that massage therapy after heart surgery

Table 2. Mean scores of anxiety before and after the intervention $(n=50)$

\begin{tabular}{lccccc}
\hline $\begin{array}{l}\text { Time } \\
\text { Variable }\end{array}$ & $\begin{array}{c}\text { Pre intervention } \\
\text { Mean } \pm \text { SD }\end{array}$ & $\begin{array}{c}\text { Day } 1 \\
\text { Mean } \pm \text { SD }\end{array}$ & $\begin{array}{c}\text { Day 2 } \\
\text { Mean } \pm \text { SD }\end{array}$ & $\begin{array}{c}\text { Day3 } \\
\text { Mean } \pm \text { SD }\end{array}$ & $F^{\mathrm{a}}$ \\
\hline $\begin{array}{l}\text { Anxiety } \\
* \mathrm{p}<0.01\end{array}$ & $43.52(10.32)$ & $40.21(6.69)$ & $38.86(7.92)$ & $33.22(5.19)$ & $72.39 *$ \\
\hline
\end{tabular}

aF, F value analyzed by using repeated measures. SD, standard deviation.

Table 3. Comparisons of Mean Differences in Pre- and Post-intervention Between Different Gender $(\mathrm{n}=50)$

\begin{tabular}{|c|c|c|c|c|}
\hline Variable & MaleMa (SD) & FemaleMa (SD) & $\mathrm{Fb} / \mathrm{Zc}$ & $\mathrm{p}$ \\
\hline Anxiety & - 10.16 (7.93) & - $8.87(5.86)$ & 7.37b & $0.01 *$ \\
\hline \multicolumn{5}{|c|}{$\begin{array}{l}* \mathrm{p}<0.05 \text {. } \\
\mathrm{aM} \text {, mean difference = mean (post-test III) - mean (pretest). } \\
\mathrm{bF}, \mathrm{F} \text { value analyzed by using multivariate analysis of variance. } \\
\mathrm{cZ}, \mathrm{Z} \text { value analyzed by using Mann-Whitney U test. } \\
\text { SD, standard deviation }\end{array}$} \\
\hline
\end{tabular}


may be pleasant but is not effective on anxiety (Baxter \& Albert ,2011.Kargar Jahromi et al,2016). But in a study at the Mayo Clinic, in which 58 cardiac surgery patients postoperatively received $1-3$ massage therapy ses-sions of 20 minutes each, created evidence compelling enough for the Mayo Clinic to hire a full-time massage therapist to be available on the inpatient unit (Cutshall et al,2007).

In adults, MT has been shown to reduce anxiety, depression, and delayed assessment of pain (Moyer ,Rounds, \& Hannum ,2004 ). The reported cardiopulmonary effects of MT in adult populations include reduction in blood pressure (BP) and heart rate (HR) and improvement in comfort, pain, anxiety, and tension after cardiac surgery (Beeken, Parks, Cory,\& Montopoli ,1998. Bauer, 2010. Cutshall et al,2010 ). There is evidence to suggest that post-exercise massage may be helpful in reducing delayed-onset muscle soreness (Hilbert, Sforzo, \& Swenson,2003). In addition, Hemmings et al. reported that massage is effective in enhancing perception of recovery after boxing (Hemmings, Smith, Graydon,\& Dyson ,2000), which may lead to improvement in subsequent performance.

It has also been shown that massage therapy reduces pain and anxiety and improves sleep quality of patients' undergone cardiovascular surgeries (Nerbass, Feltrim, Souza, Ykeda, \& Lorenzi-Filho,2010. Poorgholami et al,2016).

Field and colleagues (2002) observed that MT decreased anxiety and depressed mood and increased the number of sleep hours in patients with fibromyalgia (Field et al ,2002).

Other study has also shown that massage can relax muscles, produce calmness, reduces pain, fatigue and drowsiness and eventually leads to reduction of anxiety (Cutshall et al, 2010).

Back massage can help CHF patients be less anxious. After 1 day of massage, anxiety significantly improved. The changes in anxiety level after massage among male participants were significantly greater than those among female participants $(\mathrm{p}<001)$. Table 3.

Rose Adams, et al in their study on title of the effects of massage therapy on pain management in the acute care setting is shown that integration of massage therapy into the acute care setting creates overall positive results in the patient's ability to deal with the challenging physical and psychological aspects of their health condition(Rose, Barb, \& Cynthia, 2010 ). In Shay Beider, et al study, peak heart rate, peak VO2, and peak minute ventilation were higher when children received a massage before exercise testing(Shay Beider, Boulanger, Yann, \& Ruey, 2010).

In the present study, there were limitations inherent to the investigation itself .limitation of the present study is the lack of collection of physiological data, including heart rate, blood pressure, and oxygen levels. The absence of data on the physiological indicators means that the study relied on participant perceptions without additional external measures to verify participant responses to massage therapy. Another limitation was the lack of control of all of confounders.

The current project, designed to gather prelimi-nary data on the research hypothesis, did not use a control group. The selection of additional patients in units throughout the hospital, combined with randomization to groups, would have required sub-stantial additional resources. However, future stud-ies on massage therapy in coronary care setting may benefit from the addition of a control group.

\section{CONCLUSION}

The conclusion that back massage can be more helpful to male patients than female patients. It needs to be confirmed in an additional study with a large randomized sample size.

\section{REFERENCES}

1. Abu Ruz, M.E., Lennie, T.A, \& Moser, D.K. Effects of â-blockers and anxiety on complication rates after acute myocardial infarction. Am J Crit Care, 2011; 20; 67-73.http:/ /dx.doi.org/10.4037/ajcc2010216

2. Anderson, P.G., \& Cutshall, A.M. Massage Therapy - A comfort intervention for cardiac surgery patients. Clinical Nurse Specialist. 2007; 21: 161- 5, doi:10.1097/01.NUR. 00002 70014.97457.d5. http://dx.doi.org/10.1097/ 01.NUR. 00002700 14.97457.d5

3. Bauer, B.A., Cutshall, S.M., Wentworth, L.J., Engen, D., Messner, P.K,....\& Wood, C.M. Effect of massage therapy on pain, anxiety, and 
tension after cardiac surgery: a randomized study. Complement Ther Clin Pract. 2010; 16(2);70-75.http://dx.doi.org/10.1016/ j.ctcp.2009.06.012

4. Baxter, G.D., \& Albert, N.M. Massage therapy after heart surgery: possibly pleasant, but not effective. Focus Altern Complement Ther, 2011; 16 (1);76-77.http://dx.doi.org/10.1111/j.20427166.2010.01070_20.x

5. Beeken, J., Parks, D., Cory, J., \& Montopoli, G. The effectiveness of neuromuscular release massage therapy in five individuals with chronic obstructive lung disease. Clin Nurs Res., 1998; 7(3);309-317. http://dx.doi.org/10.1177/ 105477389800700307

6. Braun, M.B., \& Simonson, S. Introduction to Massage Therapy (3rd ed.). 2014; Philadelphia: LWW.

7. Buttagat, V., Eungpinichpong, W., Chatchawan, U.,\& Kharmwan, S. The immediate effects of traditional Thai massage on heart rate variability and stress related parameters in patients with back painassociated with myofascial trigger points. Journal of Bodyw Mov Ther, 2011; 15: 15-23.http://dx.doi.org/10.1016/ j.jbmt.2009.06.005

8. Chen, H.M., Clark, A.P., Tai, L.M., \& Lin, C.C. Self-reported health related quality of life and sleep disturbances in Taiwanese people with heart failure. J Cardiovasc Nurs, 2010; 25;503513 .http://dx.doi .org/10.1097/ JCN.0b013e3181e15c37

9. Cutshall, S.M., Fenske, L.L., Kelly, R.F., Phillips, B.R., Sundt, T.M.,....\& Bauer, B.A. Creation of a healing enhancement program at an academic medical center. Complement Ther Clin Pract, 2007; 13(4); 217-223.http:// dx.doi.org/10.1016/j.ctcp.2007.02.001

10. Cutshall, S.M., Wentworth, L.J., Engen, D., Sundt, T.M., Kelly, R.F.,.... \& Bauer, B.A. Effect of massage therapy on pain, anxiety, and tension in cardiac surgical patients: a pilot study. Complement .Ther Clin Pract. 2010; 16(2);9295.http://dx.doi.org/10.1016/j.ctcp.2009.10.006

11. Dehghan-nayeri, N., \& Adib-Hajbaghery, M. Effects of progressive relaxation on anxiety and quality of life in female students: A nonrandomized controlled trial. Complement Ther Med, 2011; 19: 194-200.http://dx.doi.org/ 10.1016/j.ctim.2011.06.002

12. Field, T., Diego, M., Cullen, C., Hernandez-Reif, M., Sunshine, W., \& Douglas, S. Fibromyalgia pain and substance $\mathrm{P}$ decrease and sleep improves after massage therapy. J Clin Rheumatol, 2002; 8;72-76, doi: 10.1097/
00124743- 200204000-00002.

13. Hemmings, B., Smith, M., Graydon, J., \& Dyson, R. Effects of massage on physiological restoration, perceived recovery, and repeated sports performance. $\mathrm{Br} J$ Sports Med. 2000; 34(2);109-115.http://dx.doi.org/10.1136/ bjsm.34.2.109

14. Hilbert, J.E., Sforzo, G.A.,\& Swenson, T. The effects of massage on delayed onset muscle soreness. Br J Sports Med., 2003; 37(1);7274.http://dx.doi.org/10.1136/bjsm.37.1.72

15. Jane, S.W., Wilkie, D.J., \& Gallucci, B.B. Systematic review of massage intervention for adult patients with cancer. Cancer Nurs, 2008; 31; 24-35.http://dx.doi.org/10.1097/ 01.NCC.0000339242.51291.85

16. Jiang, W., Kuchibhatla, M., \& Cuffe, M.S Prognostic value of anxiety and depression in patients with chronic heart failure. Circulation, 2004; 110, 3452-3456.http://dx.doi.org/10.1161/ 01.CIR.0000148138.25157.F9

17. Lashkaripour, K. The relationship between test anxiety and academic achievement in students of guidance schools in Zahedan. Tabib Shargh Journal, 2006; 84, winter 85.

18. Mahram, B. Standardization of Spielberger's test anxiety inventory in Mashhad. Allameh Tabatabaei University, Tehran 1994.

19. Martensson, J., Karlsson, J.E., \& Fridlund, B. Female patients with congestive CHF: How they conceive their life situation. J Adv Nurs , 1998; 28: 1216-1224.http://dx.doi.org/10.1046/j.13652648.1998.00827.x

20. Moser, D.K., Dracup, K., \& Evangelista, L.S. Comparison of prevalence of symptoms of depression, anxiety, and hostility in elderly patients with heart failure, myocardial infarction, and a coronary artery bypass graft. Heart Lung, 2010; 39: 378-385.http://dx.doi.org/10.1016/ j.hrtlng.2009.10.017

21. Moser, D.K.,\& Worster, P.L. Effect of psychosocial factors on physiologic outcomes in patients with CHF. J Cardiovasc Nurs 2000; 14: 106-115.http://dx.doi.org/10.1097/ 00005082-200007000-00008

22. Mousavi, M., Haghshenas, H., \& Alishahi, M.J. Effect of gender, school performance and school type on test anxiety among Iranian adolescents. Iranian Red Crescent Medical Journal, 2008; 10: 4-7

23. Moyer, C.A., Rounds, J., \& Hannum, J.W. A meta-analysis of massage therapy research. Psychol Bull., 2004; 130(1);3-18.http:// dx.doi.org/10.1037/0033-2909.130.1.3 